\title{
MAGNESIUM ISOTOPIC COMPOSITION OF OLIVINE FROM THE LITHOSPHERIC MANTLE
}

\author{
N.J. Pearson ${ }^{1}$, W.L. Griffin ${ }^{1,2}$, Suzanne Y. O'Reilly ${ }^{1}$ and G. Delpech ${ }^{1}$ \\ 1. GEMOC ARC National Key Centre, Dept. of Earth and Planetary Sciences, Macquarie University, NSW 2109, Australia \\ 2. CSIRO Exploration and Mining, North Ryde, NSW 2113
}

\section{INTRODUCTION}

Magnesium has three naturally occurring stable isotopes, ${ }^{24} \mathrm{Mg}(78.99 \%),{ }^{25} \mathrm{Mg}(10.00 \%)$ and ${ }^{26} \mathrm{Mg}$ (11.01\%).

Recent developments in multi-collector inductively coupled plasma mass spectrometry (MC-ICPMS) have stimulated renewed interest in the variations in the isotopic composition of $\mathrm{Mg}$ in geological and biological environments (Galy et al., 2000, 2001, 2002; Young et al., 2002). The data obtained by Galy and co-workers using a Nu Plasma MC-ICPMS showed the precision to be greater than an order of magnitude better than other techniques. This marked improvement in precision allowed the measurement of isotopic fractionations produced during high temperature volatilisation and/or condensation reactions and by low-temperature weathering and biological processes. Galy et al. (2000) also showed that the $\mathrm{Mg}$ isotopic abundances of terrestrial materials define a single mass fractionation curve on a Mg three-isotope plot.

This study aims to investigate isotopic variations in $\mathrm{Mg}$ in the lithospheric mantle by analysing olivine. The olivine grains analysed are from a selection of mantlederived peridotite xenoliths and megacrysts chosen to represent the lithospheric mantle beneath Archean cratons (Siberia, Kaapvaal, Slave), Phanerozoic fold belts (south-eastern Australia) and oceanic islands (Kerguelen Island).

\section{ANALYTICAL METHODS}

\section{MASS SPECTROMETRY}

$\mathrm{Mg}$ isotope ratios were measured using a $\mathrm{Nu}$ Plasma MC-ICPMS. Operating conditions for the mass spectrometer followed the method described by Galy et al. (2001). The Nu Plasma has a fixed collector array of 12 Faraday collectors and the variable dispersion ion optics are used to direct the $\mathrm{Mg}$ isotopes into the axial $\left({ }^{25} \mathrm{Mg}\right)$ and the two outermost Faradays $\left({ }^{26} \mathrm{Mg}\right.$ and $\left.{ }^{24} \mathrm{Mg}\right)$.

\section{CALIBRATION}

Olivine from the dunite at Almklovdalen (ALM-1; Fo = 92.9), Norway and spinel lherzolite xenoliths from San Carlos (SC-1; Fo = 91.1), Arizona, USA, were selected as potential laser standards. Hand-picked fragments were digested and prepared in $2 \% \mathrm{HNO}_{3}$ acid solutions with 100 to $500 \mathrm{ppb} \mathrm{Mg}$. These were analysed against SRM980 Mg and other high-purity Mg ICPMS standards. Solutions were introduced into the plasma using a CETAC MCN 6000 to reduce the introduction of $\mathrm{H}_{2} \mathrm{O}, \mathrm{CO}_{2}, \mathrm{O}_{2}$ and $\mathrm{N}_{2}$ into the plasma.

$\mathrm{Mg}$ isotopic compositions are expressed as per mil (\%o) deviation from the isotopic composition of SRM980: $\delta^{\mathrm{n}} \mathrm{Mg}=\left[\left({ }^{\mathrm{n}} \mathrm{Mg} /{ }^{24} \mathrm{Mg}\right)_{\text {sample }} /\left({ }^{\mathrm{n}} \mathrm{Mg} /{ }^{24} \mathrm{Mg}\right)_{\text {SRM980 }}-1\right] \times 1000$

The three-isotope plot of the Mg isotope ratios (Fig. 1), shows a linear relationship between SRM980, and the solution analyses of Almklovdalen and San Carlos olivines, and high purity $\mathrm{Mg}$ (SPEX). The slope of this line $(0.5165 \pm 0.0006)$ is within error of the Terrestrial Fractionation Curve of Galy et. al. (2000; slope $=$ $0.5163)$.

A solution of SRM980 spiked with high purity Fe (IRMM14) was prepared as a synthetic olivine solution to assess matrix effects on $\mathrm{Mg}$ isotopic composition.

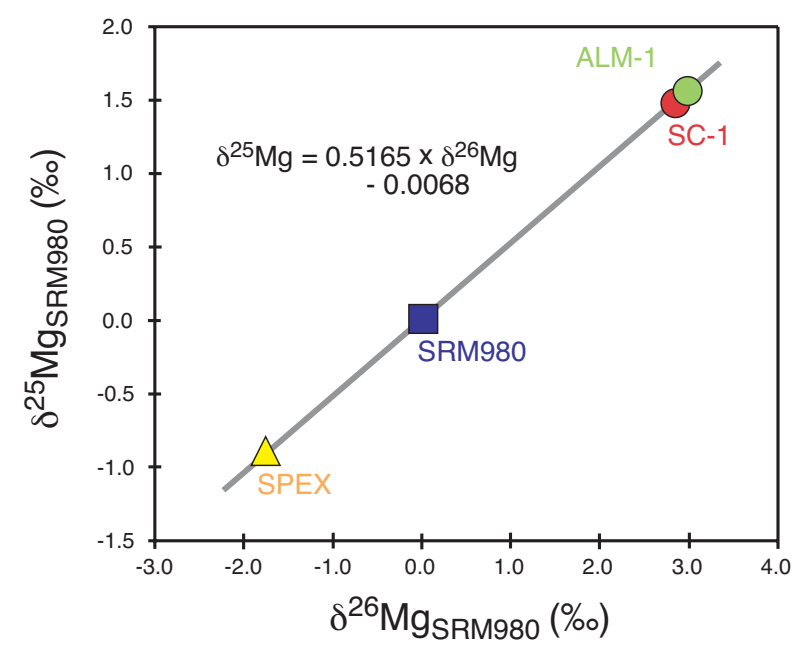

Figure 1: Magnesium three-isotope plot (relative to SRM 980 Mg standard) of SPEX Mg, ALM-1 and SC-1 solutions. 


\section{LASER ABLATION}

In situ analysis was performed using either a New Wave Merchantek LUV266 or LUV213 laser ablation system attached to the $\mathrm{Nu}$ Plasma. Ablation was done in He and then mixed with Ar before introduction into the plasma. Typical laser operating conditions include: frequency $5 \mathrm{~Hz}$, and energy of $\sim 0.1 \mathrm{~mJ}$ giving a spot size of $\sim 50 \mu \mathrm{m}$ and typical total $\mathrm{Mg}$ beam size of 7-9 volts.

The three-isotope plot of the measured $\mathrm{Mg}$ isotope ratios of ALM-1 is shown in Fig. 2. The solid line corresponds to the best fit of the data and its slope gives the value of the mass-dependent fractionation factor.

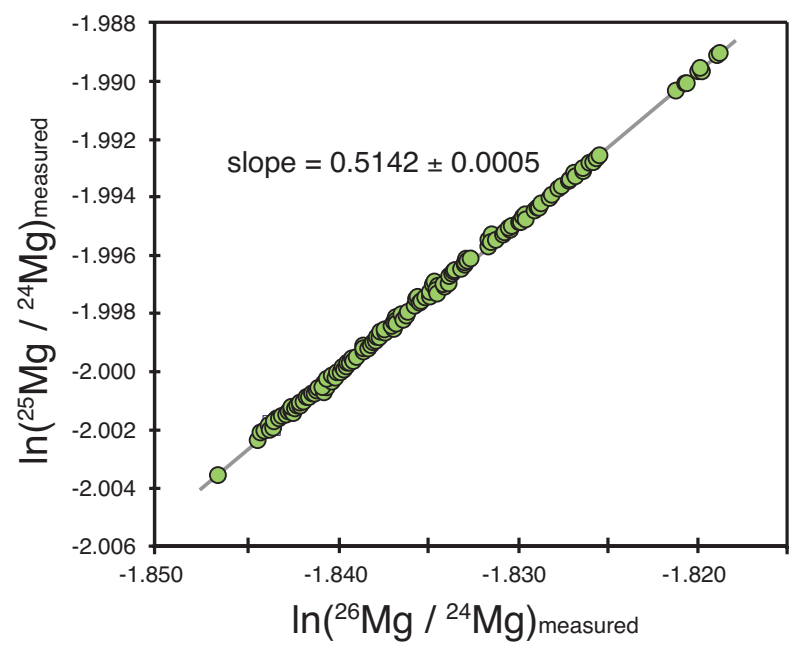

Figure 2: Magnesium three-isotope plot of laser ablation analyses of ALM-1.

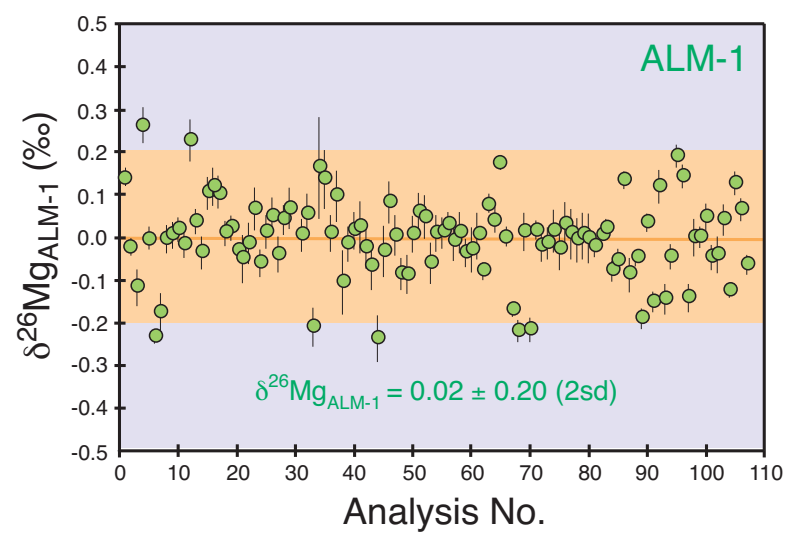

Figure 3: Reproducibility of $\delta^{26} \mathrm{Mg}$ measurements of ALM-1 by laser ablation. The shaded area corresponds to the $2 \sigma$ of the complete data set. Error bars on individual measurements are $1 \sigma$.
Replicate analyses of the Almklovdalen olivine indicate a precision of 0.20 per mil $(2 \sigma)$ for $\delta^{26} \mathrm{Mg}$ and 0.12 per

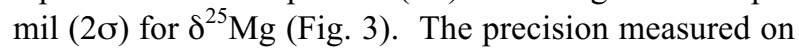
the San Carlos olivine is greater $(0.37$ per mil $(2 \sigma)$ for $\delta^{26} \mathrm{Mg}$ ) and is due to grain-to-grain differences (Fig. 4).

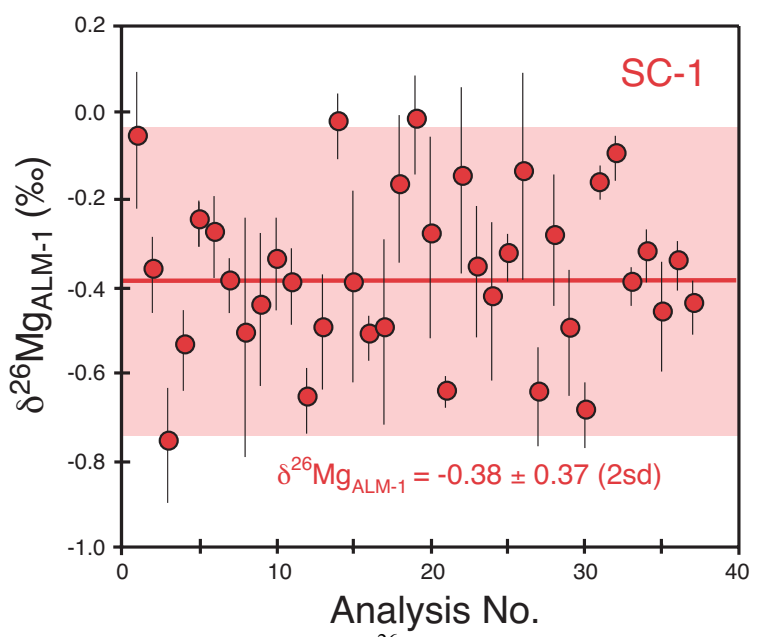

Figure 4: Reproducibility of $\delta^{26} \mathrm{Mg}$ measurements of $\mathrm{SC}-1$ by laser ablation.

\section{RESULTS}

The results for the olivines show that there are significant variations in $\delta^{26} \mathrm{Mg}$ and $\delta^{25} \mathrm{Mg}$ in the lithospheric mantle. The overall range determined for the samples analysed in this study is from 0.90 to 5.40 per mil ${ }^{26} \mathrm{Mg} /{ }^{24} \mathrm{Mg}$ and 0.35 to 2.70 per mil ${ }^{25} \mathrm{Mg} /{ }^{24} \mathrm{Mg}$. The three-isotope plot of the $\mathrm{Mg}$ isotope ratios (Fig. 5), expressed in $\delta$ units relative to SRM980, shows the in situ analyses of olivine grains from the lithospheric mantle lie on the Terrestrial Fractionation Curve determined by Galy et al. (2000).

Figure 6 shows a broad trend from lighter $\mathrm{Mg}$ isotopic compositions in more depleted Archean xenoliths to heavier compositions in the Phanerozoic samples from SE Australia and Kerguelen. However, individual grains and samples show variations in $\delta^{26} \mathrm{Mg}$ that are greater than the external precision determined for ALM-1 $( \pm 0.20,2 \mathrm{sd})$ and warrant investigation. The heterogeneities observed suggest that the processes that control $\mathrm{Mg}$ isotopic fractionation are preserved on the microscopic scale.

Samples with petrographic evidence of refertilisation (e.g. Kaapvaal and Slave sheared peridotites) or modal metasomatism (e.g. SE Australian amphibole+apatitebearing xenoliths) show large ranges in $\delta \mathrm{Mg}$ values. 


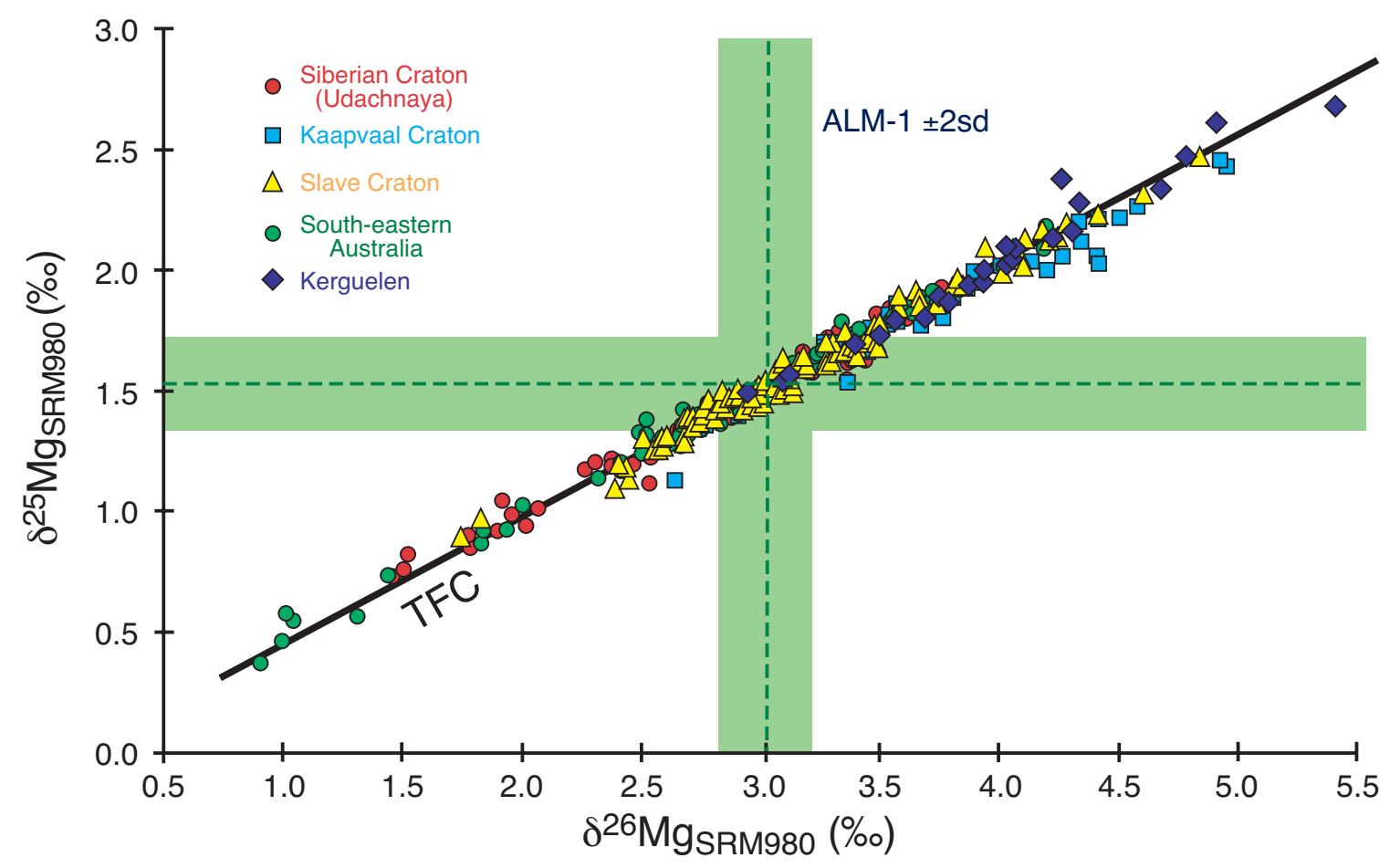

Figure 5: Magnesium three-isotope plot (relative to SRM980)

of laser ablation analyses of olivine from peridotite xenoliths and megacrysts from the lithospheric mantle.

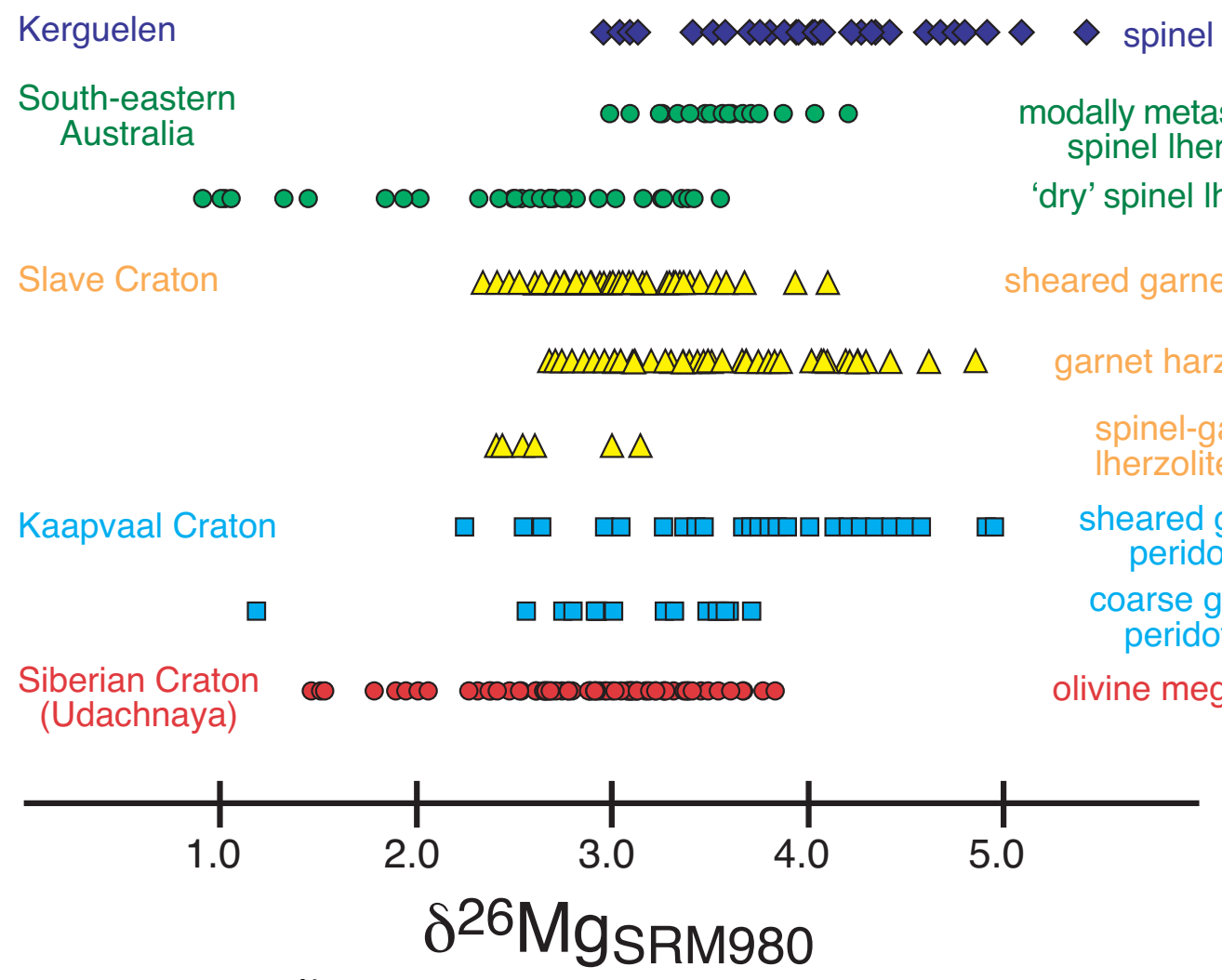

Figure 6: Range of measured $\delta^{26} \mathrm{Mg}$ (relative to SRM980) of olivine from different rock types from the Siberian, Kaapvaal and Slave Cratons, SE Australia and Kerguelen Islands. 


\section{DISCUSSION}

The effect of modal metasomatism on $\delta \mathrm{Mg}$ is evident in the 6 spinel lherzolites from SE Australia. The samples include assemblages that are 'dry' or unmetasomatised (SGN-1, DR9894), cryptically metasomatised (DR9708) and modally metasomatised (amphibole +apatite-bearing; BM650, BM655, BM901) (O’Reilly et. al., 1991). The olivine becomes more Fe-rich in the amphibole-bearing samples and the plot of $\delta \mathrm{Mg}$ versus olivine Fo shows that these samples also have the largest variation in $\delta \mathrm{Mg}$ (Fig. 7).

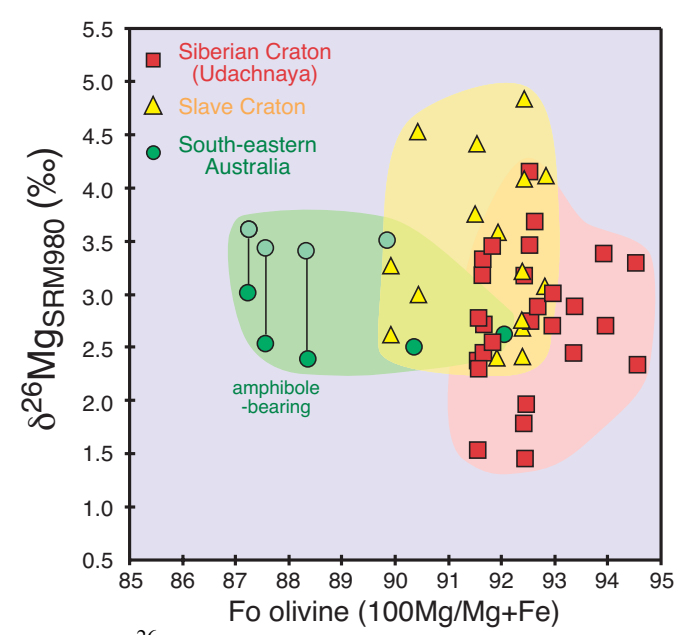

Figure 7: $\delta^{26} \mathrm{Mg}$ versus olivine composition (Fo) for samples from the Siberian Craton, Slave Craton and South-eastern Australia. Tie-lines show the range in $\delta^{26} \mathrm{Mg}$ measured within individual samples showing modal metsomatism.

The sheared peridotite xenoliths from the Kaapvaal and Slave cratons provide evidence for a shift to heavier $\delta \mathrm{Mg}$ values associated with the introduction of fluids with an 'asthenospheric' signature. There is a systematic variation between $\delta^{26} \mathrm{Mg}$, Ca content (related to temperature) and microstructure of the olivine in sample vr40332a (Fig. 8, Fig. 9). The trend to higher $\delta \mathrm{Mg}$ in the olivine neoblasts relative to porphyroclasts is also observed in vr50855a (Fig. 8). This sample is a garnet harzburgite but major element chemistry $\left(\mathrm{CaO}: \mathrm{Cr}_{2} \mathrm{O}_{3}\right)$ would classify the garnet as lherzolitic (Pearson et. al., 1999). The variation in the $\mathrm{Mg}$ isotopes of the olivine grains suggests that parts of the sample have been significantly modified by fluids moving along distinct pathways. Preliminary measurement of $\mathrm{Fe}$ isotopes in the olivine in vr50855a indicates a positive correlation between $\delta^{26} \mathrm{Mg}$ and $\delta^{56} \mathrm{Fe}$.

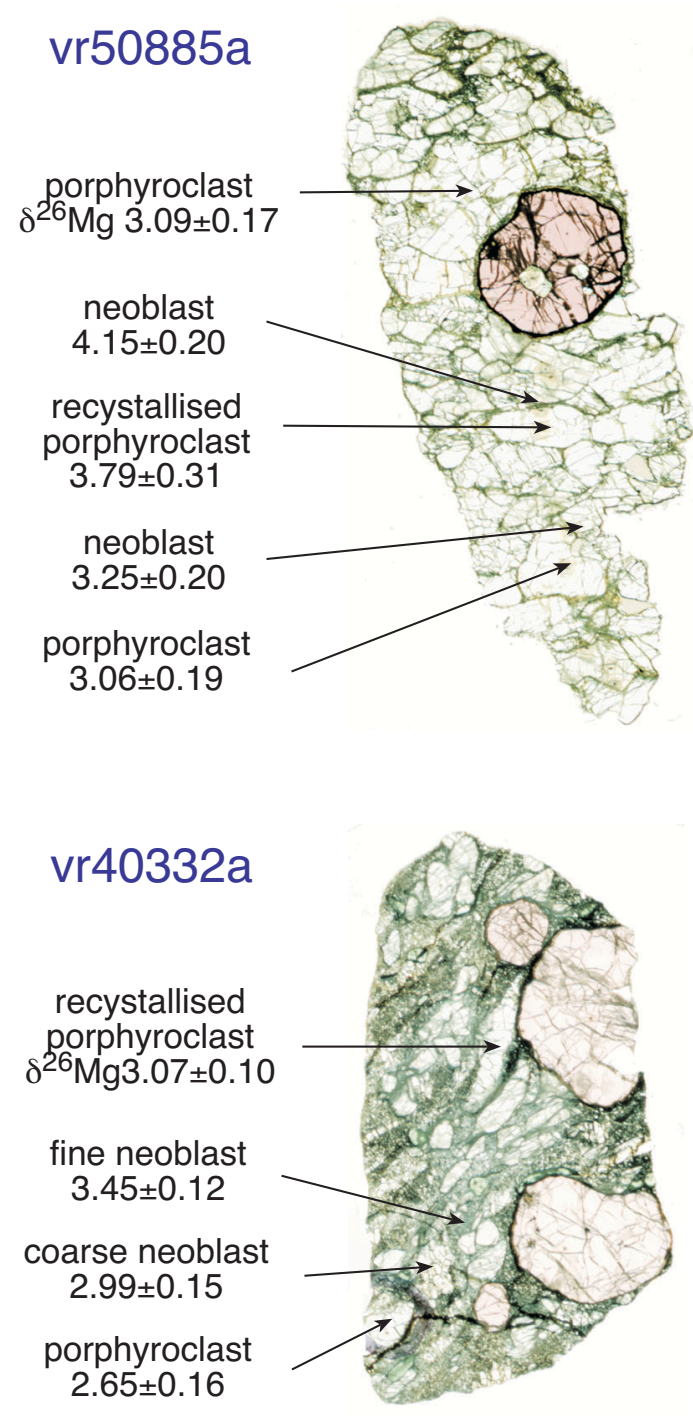

Figure 8: Variation in $\delta^{26} \mathrm{Mg}$ in olivine in samples vr50885a and vr40332a.

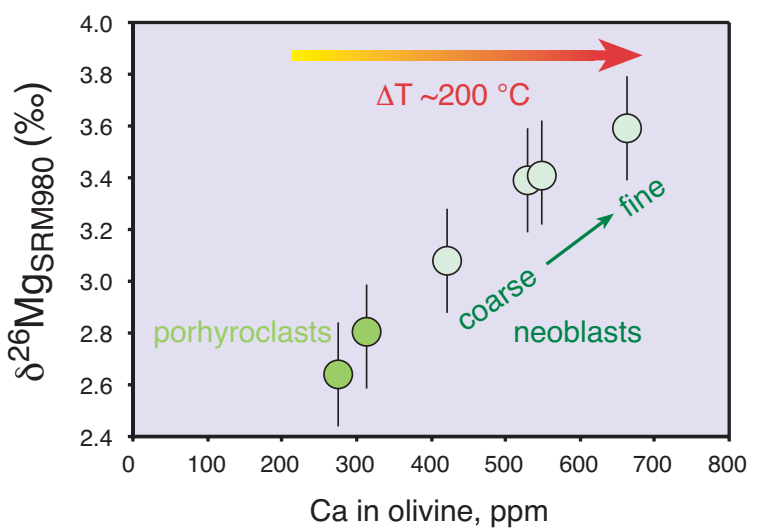

Figure 9: $\delta^{26} \mathrm{Mg}$ versus $\mathrm{Ca}(\mathrm{ppm})$ in olivine in vr40332a. 


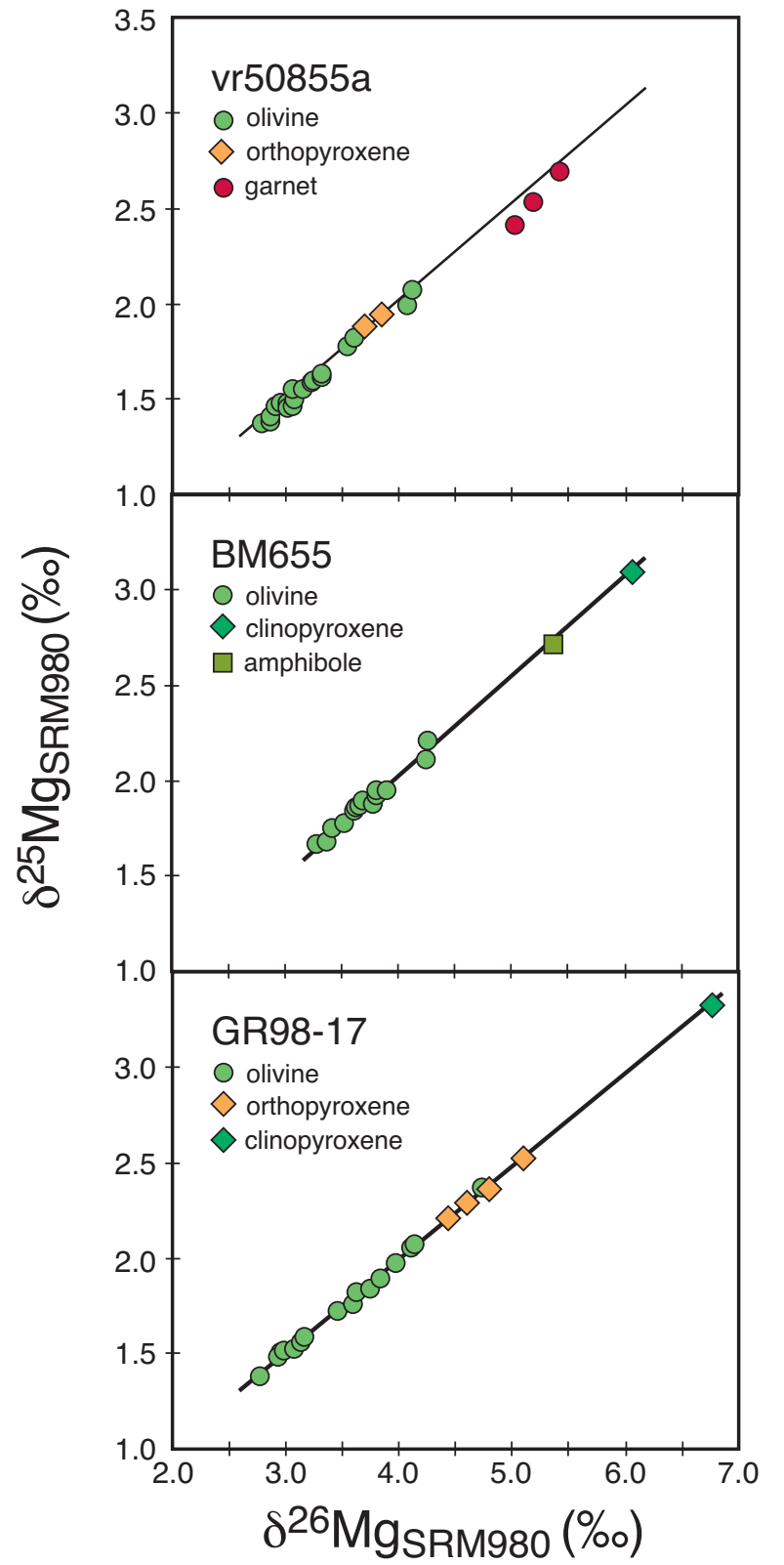

Figure 10: Magnesium three-isotope plot (relative to SRM980 Mg standard) showing the fractionation between olivine and coexisting minerals.

The three isotope plots (Fig. 10) show the fractionation of $\mathrm{Mg}$ isotopes between coexisting minerals in a garnet harzburgite (vr50885a), an amphibole-bearing spinel lherzolite (BM655) and an olivine websterite (GR9817). The systematically lighter isotopic composition of olivine relative to pyroxene and amphibole are similar to the Fe isotopic data reported by Zhu et al. (2002). The variations observed in $\delta \mathrm{Mg}$ in olivine in individual samples indicates re-equilibration and the importance of kinetic processes in isotope fractionation at high temperatures

\section{CONCLUSIONS}

The change in $\delta^{26} \mathrm{Mg}$ in olivine produced by refertilisation or metasomatism may provide a valuable new method to identify these processes. This is relevant to understanding the history of single olivine grains hosting sulfides that have been dated by the in situ Re-Os isotope method. The data obtained so far on Udachnaya olivine xenocrysts indicate that Type 3 sulfides are hosted by grains with higher $\delta \mathrm{Mg}$, implying that both sulfide and host have been affected by metasomatism (Griffin et al., 2002).

\section{REFERENCES}

Galy, A., Young, E.D., Ash, R.D., O’Nions, R.K., 2000. The formation of chondrules at high gas pressures in the Solar Nebula. Science 290, 1751-1753.

Galy, A., Belshaw, N.S., Halicz, L., O’Nions, R.K., 2001. High-precision measurement of magnesium isotopes by multiple-collector inductively coupled plasma mass spectrometry. Int. J. Mass. Spectrom. 208, 89-98.

Galy, A., Bar-Matthews, M., Halicz, L., O’Nions, R.K., 2002. $\mathrm{Mg}$ isotopic composition of carbonate: insight from speleothem formation. Earth Planet. Sci. Letts. 6248, $1-11$.

Griffin, W.L., Spetsius, Z.V., Pearson, N.J., O'Reilly, S.Y., 2002. In situ Re-Os anlaysis of sulfide inclusions in kimberlitic olivine: new constraints on depletion events in the Siberian lithospheric mantle. Geochem. Geophys. Geosystems 3, 1-25.

O’Reilly, S.Y., Griffin, W.L., Ryan, C.G., 1991. Residence of trace elements in metasomatized spinel lherzolite xenoliths: a proton-microprobe study. Contrib. Mineral. Petrol. 109, 98-113.

Pearson, N.J., Griffin, W.L., Doyle, B.J., O’Reilly, S.Y., van Achterbergh, E., Kivi, K., 1999. Xenoliths from kimberlite pipes of the Lac de Gras area, Slave Craton, Canada. In: Gurney, J., Gurney, J., Pascoe, M., Richardson, S. (Eds), Proc. $7^{\text {th }}$ Int. Kimb. Conf. Red Roof Design, Cape Town, pp 644-663.

Young, E.D., Ash, R.D., Galy, A., Belshaw, N.S., 2002. Mg isotope heterogeneity in the Allende meteorite measured by UV laser ablation-MC-ICPMS and comparisons with $\mathrm{O}$ isotopes. Geochim. Cosmochim. Acta. 66, 683-698.

Zhu, X.K., Guo, Y., Williams, R.J.P., O’Nions, R.K., Matthews, A., Belshaw, N.S., Canters, R.W., de Waal, E.C., Wester, U., Burgess, B.K., Salvato, B., 2002 Mass fractionation processes of transition metal isotopes. Earth Planet. Sci. Letts. 200, 47-62.

Contact: NJ Pearson, GEMOC ARC National Key Centre, Dept of Earth and Planetary Sciences, Macquarie University, NSW Australia 2109, E-mail: npearson@els.mq.edu.au http://www.es.mq.edu.au/GEMOC/ 